\title{
Towards a population approach for evaluating grassland restoration - a systematic review
}

\author{
Mélanie Harzé1,2 ${ }^{\circledR}$, Arnaud Monty ${ }^{1}$, Sylvain Boisson ${ }^{1}$, Carline Pitz ${ }^{1}$, Julia-Maria Hermann ${ }^{3}$, \\ Johannes Kollmann ${ }^{3,4}$, Grégory Mahy ${ }^{1}$
}

Persistence of restored populations depends on growth, reproduction, dispersal, local adaptation, and a suitable landscape pattern to foster metapopulation dynamics. Although the negative effects of habitat fragmentation on plant population dynamics are well understood, particularly in grasslands, the population traits that control grassland restoration are less known. We reviewed the use of population traits for evaluating grassland restoration success based on 141 publications (1986-2015). The results demonstrated that population demography was relatively well-assessed but detailed studies providing information on key stages of the life cycle were lacking despite their importance in determining population viability. Vegetative and generative performances have been thoroughly investigated, notably the components of plant fitness, such as reproductive output, while genetic and spatial population structures were largely ignored. More work on the population effects of ecological restoration would be welcomed, particularly with a focus on population genetics. Targeted species were principally common and dominant natives, or invasive plants while rare or threatened species were poorly considered. Evaluation of ecological restoration should be conducted at different scales of ecological complexity, but so far, communities and ecosystems are over represented, and more focus should be directed towards a population approach as population traits are essential indicators of restoration success.

Key words: fragmentation, indicators, metapopulation, plants, success

\section{Conceptual Implications}

- Evaluation of grassland restoration success should be done at different scales of ecological complexity, but so far, only few studies have employed plant population traits that are essential indicators of restoration success.

- Among population traits measured, detailed demographic studies were lacking despite their importance in determining population viability. Genetic and spatial population structures were also largely ignored.

- Habitat fragmentation has well-known negative consequences on plant populations' functioning. The success of restoration in enhancing metapopulation dynamics must therefore be of concern.

\section{Introduction}

Over the past decades, there has been an increased destruction and fragmentation of natural and seminatural habitats in many parts of the world (Balmford et al. 2005). Fragmentation has negative effects on population size and connectivity, thus affecting plant fitness and leading to increased risks of extinction (Lienert 2004; Leimu et al. 2006). Small and isolated populations are more exposed to environmental and demographic stochasticity, genetic drift, and inbreeding, that can negatively impact genetic structure, fitness, and demography (Lienert 2004). As sessile organisms, plants are particularly

threatened by habitat fragmentation (Young et al. 1996), and the consequences for plant populations have been intensely studied, for example in grasslands (Lienert 2004; Bowman et al. 2008; Adriaens et al. 2009; Vanden Broeck et al. 2015). Many grasslands are endangered by land use change, such as agricultural intensification, afforestation, and urban sprawl (Veldman et al. 2015a , 2015b; Koch et al. 2016). To quote only some examples: in California, annual grasslands have strongly decreased due to agricultural intensification, and are today highly threatened by invasion of annual exotic grasses and forbs of Mediterranean origin (Stromberg et al. 2001; Hoekstra et al. 2005); wet and dry seminatural grasslands in Western Europe have been degraded by recent land use change (Fuller 1987; Joyce \& Wade 1998; Poschlod \& WallisDeVries 2002; Römermann et al.

Author contributions: GM, AM, JK, MH conceived the idea of the review; MH collected and evaluated the publications, analyzed the data, and wrote the manuscript; $\mathrm{J}-\mathrm{MH}, \mathrm{SB}, \mathrm{CP}$ tested the methodology and contributed to publication analysis; all co-authors edited the manuscript.

${ }^{1}$ Biodiversity and Landscape Unit, Gembloux Agro-Bio Tech, University of Liege, Passage des Déportés 2, 5030 Gembloux, Belgium

${ }^{2}$ Address correspondence to M. Harzé, email melanie.harze@ulg.ac.be

${ }^{3}$ Chair of Restoration Ecology, Technical University of Munich, Emil-Ramann-Str. 6 , 85354 Freising, Germany

${ }^{4}$ Norwegian Institute of Bioeconomy Research (NIBIO), PO Box 115, 1431 Ås, Norway

(C) 2018 Society for Ecological Restoration

doi: $10.1111 /$ rec. 12663

Supporting information at:

http://onlinelibrary.wiley.com/doi/10.1111/rec.12663/suppinfo 
2005); while alpine grasslands of the Qinghai-Tibetan Plateau have been hugely degraded by overgrazing (Ma et al. 2002).

In addition to conservation measures, ecological restoration has become necessary to ensure long-term viability of threatened grassland plants. Grasslands have been targeted by restoration projects across the globe (Gibson-Roy et al. 2007), with the aim of improving ecological networks and reducing fragmentation along with its negative effects (Jongman \& Pungetti 2004). Restoration is comprised of a wide range of actions, from increasing the number of individuals of endangered species to re-creation of the reference ecosystem after land use changes. According to the Society for Ecological Restoration (2004), the ultimate goal of restoration projects is to develop an ecosystem that is self-supporting and resilient to perturbations. Numerous criteria can be employed to evaluate the success of restoration interventions (Hobbs \& Norton 1996; Piqueray et al. 2011; Harzé et al. 2015), including different disciplines (Wortley et al. 2013) as well as various ecological complexities, that is individuals, populations, communities, ecosystems, and landscapes (Ruiz-Jaen \& Aide 2005; Cristofoli \& Mahy 2010). According to Ruiz-Jaen and Aide (2005), most studies use three community or ecosystem attributes to assess restoration success, that is vegetation structure, species diversity, and ecosystem processes, while population characteristics are less represented. Among the nine attributes listed by the Society for Ecological Restoration (2004) to determine when restoration has been accomplished, none directly relates to population attributes. Indirectly, however, attributes five (restored ecosystem apparently functions normally for its ecological stage of development, and signs of dysfunction are absent) and eight (restored ecosystem is sufficiently resilient to endure the normal periodic stress events in the local environment that serve to maintain the integrity of the ecosystem) may include population traits. However, population biology can provide useful indicators of restoration success, and already, Montalvo et al. (1997) highlighted the application of population biology to ecological restoration and advocated that a restoration should be considered successful when populations are reestablished to a level that allows their long-term persistence in the landscape. Thus, restored populations must possess characteristics allowing their reproduction, growth, migration, and adaptation to the new environment.

Montalvo et al. (1997) also identified gaps in population biology that could be addressed in the context of ecological restoration. They proposed five research areas of particular importance linked to questions posed by restoration practitioners. One of these areas is related to population dynamics in fragmented landscapes, that is "the influence of the spatial arrangement of landscape elements on metapopulation dynamics and population processes such as migration." They advocated that there was a lack of knowledge concerning the effects of isolation on local adaptation and gene flow, and their impacts on the survival and dynamic of restored populations or metapopulations. They underscored the use of demographic data and, notably, transition matrix models to explore population viability (Menges 1990) and argued that studies on genetic diversity and structure are necessary to better comprehend metapopulation dynamics and long-term population viability (Hastings \& Harrisson 1994).

Twenty years after Montalvo et al. (1997), we assessed how these recommendations have been taken into account with respect to grassland restoration. Specifically, we addressed the following questions: (1) To what extent has a population approach been used to evaluate the success of grassland restoration? (2) Which traits have mainly been examined? and (3) How often have metapopulation dynamics been considered in ecological restoration? To answer these questions, we reviewed the scientific literature and concentrated on grassland restoration and plant species population indicators.

\section{Methods}

A systematic review of the peer-reviewed scientific literature was conducted using the electronic database "Scopus" with the following search terms (1986-2015): "grassland* AND (restoration OR reclamation OR rehabilitation)" in the title, keywords, or abstract; only publications with an English abstract were selected. The resulting 3,105 papers were individually screened and classified into four categories based on title, abstract, and content if needed with a dichotomous key (Fig. 1). (1) Papers that were not evaluating the results of grassland restoration were discarded as "not grassland restoration." It represented 2,049 papers (66\%, Fig. 1). An ecosystem was considered a "grassland" when the authors employed the term grassland either in the title, keywords, or abstract. Certain actions must have been realized in the context of a degraded ecosystem with the aim to restore, create, or rehabilitate grassland, irrespective of the state of the ecosystem before. We did not take "passive restoration" into account, defined as natural regeneration without active human intervention, mainly after the removal of persistent disturbances (Holl \& Aide 2011). A total of 1,056 papers $(34 \%$, Fig. 1) evaluated the results of grassland restoration and were therefore considered for the next step. (2) Papers evaluating the results of grassland restoration but not dealing with plant species were discarded as "not plant species." (3) Papers evaluating the results of grassland restoration and addressing plant species but not using a population approach were removed as "not population approach." (4) Finally, papers assessing the results of grassland restoration with plant species taking a population approach were selected.

All papers were sorted by the first author. To determine reproducibility, a subset of 315 papers (circa 10\%) was independently classified by three other scientists following the same protocol. The quality of reviewing these papers was established by the percentage of agreement between the reviewers using Cohen's kappa statistic $(\kappa)$, which adjusts the proportion of records for which there is agreement by the amount of agreement expected by chance alone (Cohen 1960). Agreement among the reviewers was substantial $(\kappa>0.6)$ between one pair, and moderate $(\kappa>0.4)$ between five pairs of reviewers; agreement can be considered "fair" when $\kappa>0.2$ (Landis \& Koch 1977).

The selected papers were carefully examined and the following information was traced in the text: (1) study species, 


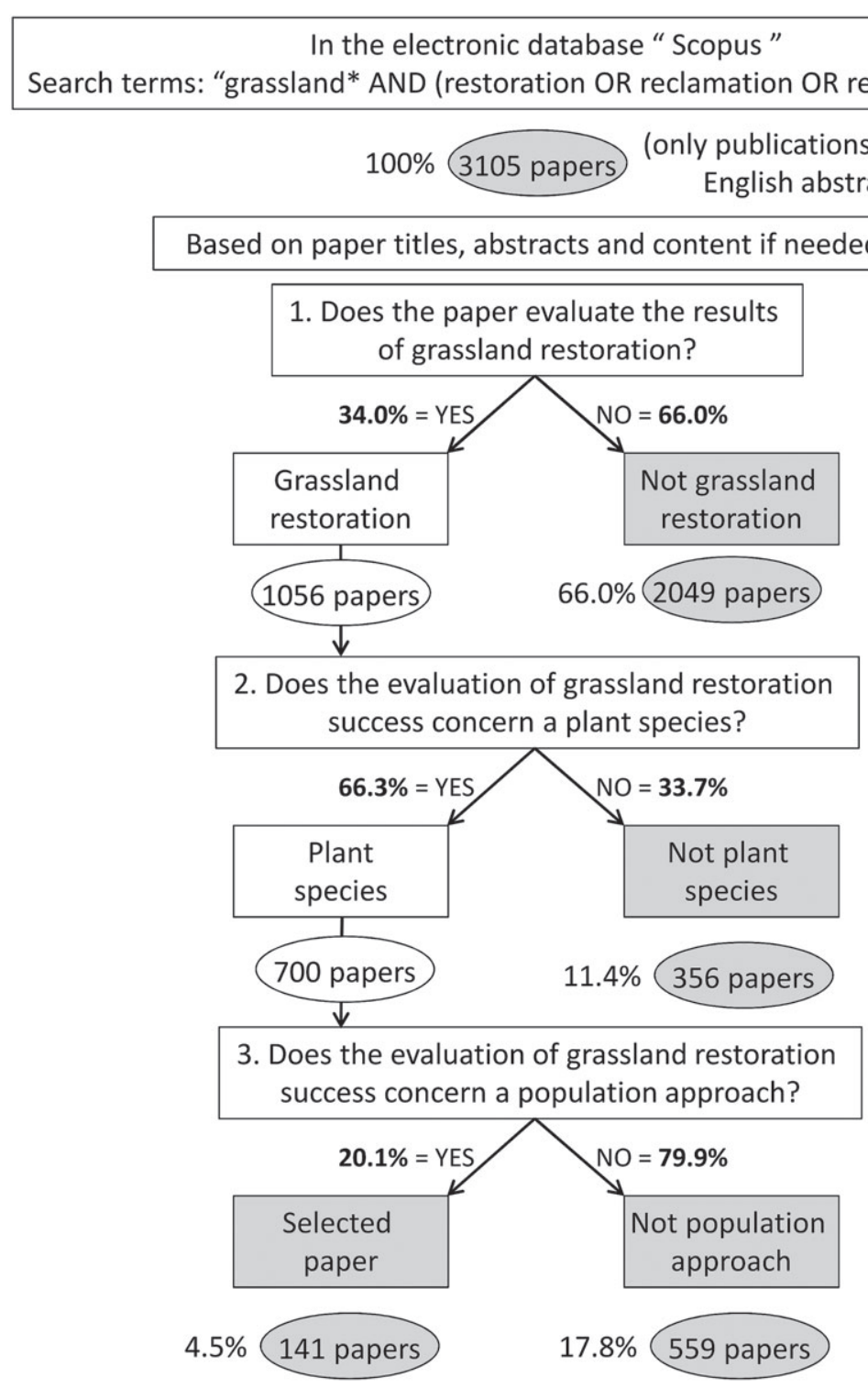

Figure 1. A dichotomous key was utilized to classify papers into four categories ("not grassland restoration," “not plant species," "not population approach," and "selected paper") based on titles, abstracts, and content if needed.

including number, functional type (grass, forb, shrub, fern), and plant descriptors (native, invasive, weed, rare, common, dominant, typical); (2) population traits for evaluating restoration success; (3) time since restoration and years of post-restoration monitoring; and (4) research area of the paper. The population traits recorded were grouped into six classes according to the literature (Silvertown \& Charlesworth 2001; Ricklefs \& Miller 2005) and expert recommendations; individual papers may have utilized more than one trait class (Table 1). The first three classes of population traits concerned population structure and were divided into (1) genetic structure (allele frequency and genotypes); (2) spatial structure (distance between individual, localization, density, etc.); and (3) demographic structure (population size, age and stage structure, etc.). Population performance was then divided into (4) vegetative performance and
(5) reproductive performance. The last class of traits concerned changes in the demographic structure through time based on population dynamics, also called (6) population demography (Silvertown \& Charlesworth 2001; Ricklefs \& Miller 2005). All selected papers are listed in Table S1 (Supporting Information) with the classes of traits used for the population approach of each paper.

\section{Results and Discussion}

Few Papers Employed a Population Approach to Evaluate Grassland Restoration

Among the 1,056 papers evaluating grassland restoration success surveyed, 66\% used plant taxa as indicator (Fig. 1). As 
Table 1. Population traits were grouped into six classes according to the literature and expert recommendations.

Classes of Population Traits

1. Genetic structure

2. Spatial structure

3. Demographic structure

4. Vegetative performance

5. Reproductive performance

6. Demography
Examples of Traits

Genetic diversity, ploidy levels, gene flow

Dispersal distance, occurrence within the landscape

Population size, life stages structure

Aboveground biomass, leaves number, vegetative height

Number of flowers, fruits or seeds, seed germinability

Adults survival, seedling emergence, population growth rate interventions to restore grasslands are essentially focused on vegetation management or plant species addition, and as targeted habitats are mostly described by vegetation composition, it is consistent that restoration evaluation focused on plants. It was already noted by Ruiz-Jaen and Aide (2005) that plant richness was the most common measure of diversity recovery.

Among the papers utilizing plant taxa to assess grassland restoration, approximately $80 \%$ did not include population traits, and instead mainly focused on community or ecosystem traits (Fig. 1). Hence, population biology is still not fully included in the evaluation of grassland restoration success. This may be explained by the fact that the standardized methods proposed by the Society for Ecological Restoration (2004) to determine accomplishing restoration are related to higher ecological complexities than populations. The European Commission also concentrated on restoration in terms of ecosystem goals and their services (Decleer 2012). Moreover, population studies, primarily addressing several target species, have often been criticized because the information recorded is considered too restricted compared to the diversity of ecosystem biodiversity components (Franklin 1993). Results from a population approach concerned one or a few species studied in specific sites, which is hardly generalizable to other species with different site conditions. Finally, it may be considered too time consuming and expensive to measure detailed population traits compared to species abundance for example.

A population approach has been considered particularly relevant when targeting keystone, umbrella, indicator, rare, or threatened species (Carignan \& Villard 2002; Cristofoli \& Mahy 2010). Roughly $60 \%$ of the 141 selected papers considered one or two species, while only $12 \%$ of the papers considered rare or threatened species. Other targeted species were described as common native species (23\%), dominant native species $(23 \%)$, typical native species (18\%), or invasive species (20\%). Selected studies were principally localized in Europe (62 papers) and in North America (60 papers). In North America, targeted species were invasive species in $23 \%$ of papers, while rare species concerned $10 \%$ of papers. In Europe, common and dominant local species were mainly studied (50\%), while invasive species concerned $16 \%$ and rare or threatened species concerned $11 \%$ of the papers.

Plant invasions are a major threat to ecosystems (Usher 1988; Hobbs 2000) and can drastically diminish the chances of successful restoration (Johnston 2011). Therefore, weeds and invasive species were particularly well-studied-one-third of the selected papers evaluated the success of restoration of invaded habitats. This was related to 31 taxa (12 forbs, 11 grasses, 7 shrubs or woody species, and 1 fern). California grasslands, for example, experienced one of the most drastic biological invasions, with almost complete conversion from native to exotic annuals (Hamilton 1997). Restoration of invaded grasslands and the way local grassland populations dealt with invasive populations is therefore quite extensively studied, particularly in North America (e.g. Kimball \& Schiffman 2003; Gillespie \& Allen 2004; Moyes et al. 2005; Cox \& Allen 2011).

\section{Genetic and Spatial Population Structures Are Largely Ignored}

Demography describes changes in population size over time. It was the class of population traits most often employed to evaluate grassland restoration (77\%, 109 papers). Specifically, this concerned traits including number of emerged seedlings or individual survival through time using one to 64 species, mostly forbs (40\%, 56 papers). Detailed demographic processes were poorly studied-just $8 \%$ (11 papers) of the selected papers followed individual fate and, among them, only $3 \%$ (four papers) employed demographic models of population growth and identified critical life history stages for population survival. Demographic studies providing information on the most crucial stages of the life cycle are useful for evaluating population viability (Lande 1988; Oostermeijer et al. 2003), and allow predictions of future growth of populations (Schemske et al. 1994; Oostermeijer et al. 2003). Moreover, demographic studies are usually considered of more immediate importance than population genetics for determining short-term population viability (Lande 1988). Indeed, decreases in the success of a critical step during the life cycle may directly affect population recruitment many generations before negative genetic effects appear (Lande 1988; Ouborg et al. 1991; Morgan 1998). On the other hand, such pluriannual demographic studies are time-consuming and much effort is needed by researchers compared to less-detailed demographic studies or those targeting simply one stage of population dynamic.

Population performances were the second most assessed class of traits $(63 \%, 89$ papers), primarily encompassing vegetative performances described through aboveground biomass and vegetative height (Table 2); half of the study species were forbs while the other half were grasses. Reproductive performances were principally described through flower, seed, and fruit production. Vegetative and reproductive performances are often linked, and the final measure of population performance is individual fitness, that is population ability to produce offspring (Begon et al. 1990). Morphological traits influence reproductive traits and, in turn, final fitness. According to Violle et al. (2007), the three major components of plant fitness are vegetative biomass, reproductive output (number of seeds produced), 
Table 2. Traits used to describe vegetative or reproductive plant performance. A paper may have employed more than one trait to describe population performance, including traits describing both vegetative and reproductive performances.

\begin{tabular}{lclr}
\hline Traits Used to Describe Vegetative Performance & $\begin{array}{c}\text { Number of } \\
\text { Papers (out of 73) }\end{array}$ & $\begin{array}{c}\text { Number of } \\
\text { Traits Used to Describe Reproductive Performance }\end{array}$ & Papers (out of 49) \\
\hline Aboveground biomass & 40 & Flower production & 31 \\
Vegetative height & 35 & Seed production & 15 \\
Number of stems & 16 & Fruit production & 9 \\
Size (basal diameter or area) & 12 & Flower or seed or fruit size & 8 \\
Belowground biomass & 7 & Seed germinability & 7 \\
Leaves number or size & 6 & Reproductive height & 6 \\
Observed vegetative vigor & 4 & Reproductive biomass & 4 \\
& & Recruitment & 3 \\
\hline
\end{tabular}

and plant survival, and all have been relatively well-assessed with regard to evaluating grassland restoration success to date.

The genetic structure of restored populations was addressed in 10 papers $(7 \%)$ via two distinct approaches. First, five papers assessed the impact of restoration by seeding and/or the impact of seed origin (local vs. nonlocal) on the population genetic structure of one to three species, including seven forbs and six grasses. Baer et al. (2014) observed that cultivars of Sorghastrum nutans were genetically different from populations of the regional ecotype, while the genetic diversity of the two seed sources was similar. In kind, Selbo and Snow (2005) as well as Gustafson et al. (2004) found no differences in genetic diversity between local remnant and seeded populations or cultivars of Andropogon gerardii and S. nutans. Smulders et al. (2000) determined a significant founder effect caused by the reintroduction of a limited number of seeds for Cirsium dissectum and Succisa pratensis. Finally, Delaney and Baack (2012) assessed the risk of hybridization for 38 species (11 grasses and 27 forbs) between remnant and introduced genotypes that would potentially lead to outbreeding depression. They found that restorations were likely to create mixed ploidy populations, leading to lower reproductive success. Restoration genetics is a field that arose from the increasing need for species translocation with the intent of restoration (Young et al. 2005). It has provoked new questions concerning the consequences of seed sampling protocols or local adaptation (Hufford \& Mazer 2003). More genetic research combined with long-term monitoring is necessary to establish the success of plant species' population restoration and to evaluate their evolutionary potential in the face of future environmental change. Secondly, five papers addressed the genetic consequences for populations restored in fragmented landscapes. We will discuss this point later.

The class of population traits least employed to evaluate grassland restoration was the spatial structure of populations. It was addressed in eight papers $(6 \%)$ that primarily focused on forbs. Globally, those papers assessed the recolonization ability of targeted species and tested whether species dispersal was the limiting factor for a successful restoration. This was the case for Silaum silaus and Serratula tinctoria in restored floodplain grasslands (Bischoff 2000, 2002), and for 16 species of seminatural grasslands (Öster et al. 2009a). The role of mobile links, such as sheep (Freund et al. 2014), was also studied with regard to grassland restoration. In the appraisal of grassland restoration, recruitment ability as a limiting factor to restore populations was more often evaluated than species dispersal. This may be explained by the fact that out of the 141 papers selected, just $30(21 \%)$ examined grassland restoration without any species addition while 111 papers (79\%) did so after introducing seeds, hay, or transplant, thus short-cutting the dispersal filter in restoration. Out of those eight papers, only one investigated the role of spatial isolation of populations in restoration success (Moore et al. 2011).

The more frequent use of simple traits related to population demography (seedling or juvenile stages) or vegetative performance may be explained by the fact that detailed genetic studies are more costly, and that long-term demographic studies are time-consuming and laborious. Moreover, when the number of study species increases, a choice must be made among population processes that could be taken into account.

\section{Research on Reduced Population Fragmentation Is Scarce}

Five of the 10 papers assessing the genetic structure of restored populations analyzed the genetic consequences for populations restored in fragmented landscapes. Gustafson et al. (2002) showed that restored grassland populations of Dalea purpurea had greater genetic diversity relative to remnant populations in a highly fragmented landscape. They advocated that metapopulations are maintained throughout the landscape by frequent local gene flow and because restorations have been realized with seeds from multiple source populations. In the same way, Helsen et al. (2013b) did not observe a decrease in genetic diversity in recently restored populations of Origanum vulgare, indicating that spontaneous colonization after habitat restoration can lead to viable populations within a short time, especially when several source populations are located nearby. However, Aavik et al. (2013) found that there was low gene flow between sown and natural populations of Lychnis flos-cuculi. Jacquemyn et al. (2010) emphasized the absence of gene flow between remnant populations of Cirsium acaule in a severely fragmented landscape that affected genetic diversity of plant populations and decreased the success of restoration-none of the recently restored areas was occupied by the study species. Finally, Rico et al. (2014) tested the effect of rotational shepherding on the demographic and genetic connectivity of a calcareous grassland 
species, demonstrating that populations of ungrazed sites (not linked by sheep grazing) had less genetic diversity than grazed populations. Those five studies targeted the key research area proposed by Montalvo et al. (1997) regarding the influence of the spatial arrangement of landscape elements on metapopulations, centered on one or two insect-pollinated forb species. The genetic structure of wind-pollinated species is less likely to be affected by fragmentation, and grasses generally perform better than forbs in restored habitats (Pywell et al. 2003). This of course does not answer the question of why other restoration studies that included forbs did not take metapopulations into account.

The negative consequences of habitat fragmentation on plant populations are well-known (Lienert 2004), particularly those on genetic structure (Hufford \& Mazer 2003). Along these lines, restoration is needed to enhance ecological networks of habitats, to reduce the genetic threats of fragmentation on plant species, and to ensure long-term viability of threatened plant populations. However, restoration may also signify a risk for populations. Indeed, when restoration relies on the spontaneous colonization of restored habitats, founder populations can be small and represent just a minor proportion of the genetic diversity of the source population (Montalvo et al. 1997; Hufford \& Mazer 2003). This can be based on a lack of seed source, low dispersal capabilities in space and time, the absence of dispersal agents, or germination problems (Bakker \& Berendse 1999; Coulson et al. 2001; Öster et al. 2009b; Helsen et al. 2013a). Small and genetically less diverse populations have reduced survival over the long term because of the effects of demographic, genetic, and environmental stochasticity (Menges 1991; Ellstrand \& Elam 1993). Moreover, plant populations that have been isolated for a long period of time within the landscape may be characterized by a high genetic differentiation among populations, representing the major proportion of genetic diversity for the species (Hensen et al. 2010; Wagner et al. 2011). Restoration with commercial seed sources or with genetically distinct source populations may potentially alter the genetic structure of local remnant populations, lead to outbreeding depression and compromising their fitness (Hufford \& Mazer 2003).

In this context, the evaluation of restoration success considering the genetic structure of populations is necessary but still largely deficient. This research area represents a considerable gap in the literature on the evaluation of grassland restoration success. Knowing the potentially deleterious outcomes, and especially the genetic effects, of habitat fragmentation on plant species populations, it is now necessary to determine the efficacy of grassland restoration protocols to counteract this threat.

\section{Conclusions}

Twenty years after Montalvo et al. (1997) identified gaps in population biology research that could be addressed in the context of ecological restoration, population indicators are still infrequently used for evaluation of grassland restoration success. Despite knowing the consequences of habitat fragmentation on plant populations, the success of restoration in enhancing metapopulation dynamics through the creation of a connected network of habitats has only been rarely taken into account in grassland ecological restoration efforts.

Several targeted species may not be able to colonize restored areas, particularly in fragmented landscapes. When restoration goals focus on the recovery of those species, population parameters are fully relevant to gauge restoration success. Deeper research on the cause of colonization or germination failure is needed for those species. Moreover, it may be necessary to evaluate methods to best apply their reintroduction through seed addition or transplants in restored sites. Targeted species may be rare plants, depending on specific dispersal agents, being highly specialized or having few seed sources available in the surrounding. In addition, as invasive species are one of the main threats to ecosystems and an impediment to successful restoration (Usher 1988; Hobbs 2000), evaluating methods to eradicate invasive populations are needed and a population perspective is fully relevant in this context. Hopefully, our review stimulates future research on grassland restoration and the assessment of restoration success from a population perspective over the next 20 years.

\section{Acknowledgments}

This study was funded by the Belgian Fonds National de la Recherche Scientifique (FNRS). We acknowledge financial support from the Patrimoine of the University of Liège. Finally, we wanted to thank V. Wagner and an anonymous reviewer for their helpful comments on a previous version of the manuscript.

\section{LITERATURE CITED}

Aavik T, Holderegger R, Edwards PJ, Billeter R (2013) Patterns of contemporary gene flow suggest low functional connectivity of grasslands in a fragmented agricultural landscape. Journal of Applied Ecology 50:395-403

Adriaens D, Jacquemyn H, Honnay O, Hermy M (2009) Conservation of remnant populations of Colchicum autumnale - the relative importance of local habitat quality and habitat fragmentation. Acta Oecologica 35:69-82

Baer SG, Gibson DJ, Gustafson DJ, Benscoter AM, Reed LK, Campbell RE, Klopf R, Willand JE, Wodika BR (2014) No effect of seed source on multiple aspects of ecosystem functioning during ecological restoration: cultivars compared to local ecotypes of dominant grasses. Evolutionary Applications 7:323-335

Bakker JP, Berendse F (1999) Constraints in the restoration of ecological diversity in grassland and heathland communities. Trends in Ecology \& Evolution 14:63-68

Balmford A, Bennun L, Ten Brink B, Cooper D, Côté IM, Crane P, et al. (2005) The convention on biological diversity's 2010 targets. Science 307:212-213

Begon M, Harper JL, Townsend CR (1990) Ecology: individuals, populations and communities. Blackwell Science, Oxford, United Kingdom

Bischoff A (2000) Dispersal and re-establishment of Silaum silaus (L.) in floodplain grassland. Basic and Applied Ecology 1:125-131

Bischoff A (2002) Dispersal and establishment of floodplain grassland species as limiting factors in restoration. Biological Conservation 104:25-33

Bowman G, Perret C, Hoehn S, Galeuchet DJ, Fischer M (2008) Habitat fragmentation and adaptation: a reciprocal replant-transplant experiment among 15 populations of Lychnis flos-cuculi. Journal of Ecology 96:1056-1064

Carignan V, Villard M-A (2002) Selecting indicator species to monitor ecological integrity: a review. Environmental Monitoring and Assessment 78:45-61 
Cohen J (1960) A coefficient of agreement for nominal scale. Educational and Psychological Measurement 20:37-46

Coulson SJ, Bullock J, Stevenson MJ, Pywell RF (2001) Colonization of grassland by sown species: dispersal versus microsite limitation in responses to management. Journal of Applied Ecology 38:204-216

Cox RD, Allen EB (2011) The roles of exotic grasses and forbs when restoring native species to highly invaded southern California annual grassland. Plant Ecology 212:1699-1707

Cristofoli S, Mahy G (2010) Restauration écologique: Contexte, contraintes et indicateurs de suivi. Biotechnology, Agronomy, Society and Environment 14:203-211

Decleer K (2012) The new European biodiversity strategy: a challenge to the restoration community. Ecological Restoration 30:93-94

Delaney JT, Baack EJ (2012) Intraspecific chromosome number variation and prairie restoration - a case study in Northeast Iowa, U.S.A. Restoration Ecology 20:576-583

Ellstrand NC, Elam DR (1993) Population genetic consequences of small population size: implications for plant conservation. Annual Review of Ecology and Systematics 24:217-242

Franklin JF (1993) Preserving biodiversity: species, ecosystems or landscape? Journal of Applied Ecology 3:202-205

Freund L, Eichberg C, Retta I, Schwabe A (2014) Seed addition via epizoochorous dispersal in restoration: an experimental approach mimicking the colonization of bare soil patches. Applied Vegetation Science 17:74-85

Fuller R (1987) The changing extent and conservation interest of lowland grasslands in England and Wales: a review of grassland surveys 1930-1984. Biological Conservation 40:281-300

Gibson-Roy P, Delpratt J, Moore G (2007) Restoring western (basalt) plains grassland. 2. Field emergence, establishment and recruitment following direct seeding. Ecological Management and Restoration 8:123-132

Gillespie IG, Allen EB (2004) Fire and competition in a southern California grassland: impacts on the rare forb Erodium macrophyllum. Journal of Applied Ecology 41:643-652

Gustafson DJ, Gibson DJ, Nickrent DL (2002) Genetic diversity and competitive abilities of Dalea purpurea (Fabaceae) from remnant and restored grasslands. International Journal of Plant Sciences 163:979-990

Gustafson DJ, Gibson DJ, Nickrent DL (2004) Conservation genetics of two co-dominant grass species in an endangered grassland ecosystem. Journal of Applied Ecology 41:389-397

Hamilton J (1997) Changing perceptions of pre-European grasslands in California. Madrono 44:311-333

Harzé M, Mahy G, Bizoux J-P, Piqueray J, Monty A (2015) Specialist plant species harbour higher reproductive performances in recently restored calcareous grasslands than in reference habitats. Plant Ecology and Evolution 148: $181-190$

Hastings A, Harrisson S (1994) Metapopulation dynamics and genetics. Annual Review of Ecology and Systematics 25:167-188

Helsen K, Hermy M, Honnay O (2013a) Spatial isolation slows down directional plant functional group assembly in restored semi-natural grasslands. Journal of Applied Ecology 50:404-413

Helsen K, Jacquemyn H, Hermy M, Vandepitte K, Honnay O (2013b) Rapid buildup of genetic diversity in founder populations of the gynodioecious plant species Origanum vulgare after semi-natural grassland restoration. PLoS One 8:e67255

Hensen I, Kilian C, Wagner V, Durka W, Pusch J, Wesche K (2010) Low genetic variability and strong differentiation among isolated populations of the rare steppe grass Stipa capillata L. in Central Europe. Plant Biology 12:526-536

Hobbs R (2000) Invasive species in a changing world. Island Press, Washington D.C.

Hobbs R, Norton DA (1996) Towards a conceptual framework for restoration ecology. Restoration Ecology 4:93-110

Hoekstra JM, Boucher TM, Ricketts TH, Roberts C (2005) Confronting a biome crisis: global disparities of habitat loss and protection. Ecology Letters 8:23-29
Holl K, Aide T (2011) When and where to actively restore ecosystems? Forest Ecology and Management 261:1558-1563

Hufford KM, Mazer SJ (2003) Plant ecotypes: genetic differentiation in the age of ecological restoration. Trends in Ecology \& Evolution 18:147-155

Jacquemyn H, Roldan-Ruiz I, Honnay O (2010) Evidence for demographic bottlenecks and limited gene flow leading to low genetic diversity in a rare thistle. Conservation Genetics 11:1979-1987

Johnston DB (2011) Movement of weed seeds in reclamation areas. Restoration Ecology 19:446-449

Jongman RHG, Pungetti G (2004) Ecological networks and greenways: concept, design, implementation. Cambridge University Press, Cambridge, United Kingdom

Joyce CB, Wade MW (1998) Wet grasslands: a European perspective. In: Joyce CB, Wade PM (eds) European wet grasslands: biodiversity, management and restoration. John Wiley, Chichester, United Kingdom

Kimball S, Schiffman PM (2003) Differing effects of cattle grazing on native and alien plants. Conservation Biology 17:1681-1693

Koch C, Conradi T, Gossner MM, Hermann JM, Leidinger J, Meyer ST, Overbeck G, Weisser WW, Kollmann J (2016) Effects of management intensity and temporary conversion to other land use on plant diversity and species composition of subtropical grasslands in southern Brazil. Applied Vegetation Science 19:553-749

Lande R (1988) Genetics and demography in biological conservation. Science 241:1455-1460

Landis J, Koch G (1977) The measurement of observer agreement for categorical data. Biometrics 33:159-174

Leimu R, Mutikainen P, Koricheva J, Fischer M (2006) How general are positive relationships between plant population size, fitness and genetic variation? Journal of Ecology 94:942-952

Lienert J (2004) Habitat fragmentation effects on fitness of plant populations - a review. Journal for Nature Conservation 12:53-72

Ma YS, Lang BN, Li QY, Shi JJ, Dong QM (2002) Study on rehabilitating and rebuilding technologies for degenerated alpine meadow in the Changjiang and Yellow river source region. Pratacultural Science 19:1-4

Menges ES (1990) Population viability analysis for an endangered plant. Conservation Biology 4:52-62

Menges ES (1991) The application of minimum viable population theory to plants. Oxford University Press, New York

Montalvo AM, Williams SL, Rice KJ, Buchmann SL, Cory C, Handel SN, Nabhan GP, Primack R, Robichaux RH (1997) Restoration biology: a population biology perspective. Restoration Ecology 5:277-290

Moore KA, Harrison SP, Elmendorf SC (2011) Can spatial isolation help predict dispersal-limited sites for native species restoration? Ecological Applications 21:2119-2128

Morgan JW (1998) Composition and seasonal flux of the soil seed bank of species-rich Themeda triandra grasslands in relation to burning history. Journal of Vegetation Science 9:145-156

Moyes AB, Witter M, Gamon JA (2005) Restoration of native perennials in a California annual grassland after prescribed spring burning and solarization. Restoration Ecology 13:659-666

Oostermeijer JGB, Luijten SH, den Nijs JCM (2003) Integrating demographic and genetic approaches in plant conservation. Biological Conservation 113:389-398

Öster M, Ask K, Cousins SAO, Eriksson O (2009a) Dispersal and establishment limitation reduces the potential for successful restoration of semi-natural grassland communities on former arable fields. Journal of Applied Ecology 46:1266-1274

Öster M, Ask K, Römermann C, Tackenberg O, Eriksson O (2009b) Plant colonization of ex-arable fields from adjacent species-rich grasslands: the importance of dispersal vs. recruitment ability. Agriculture, Ecosystems and Environment 130:93-99

Ouborg NJ, Van Treuren R, Van Damme JMM (1991) Morphological variation and fitness components in populations of varying size of Salvia pratensis L. and Scabiosa columbaria L. Oecologia 86:359-367

Piqueray J, Bottin G, Delescaille L-M, Bisteau E, Colinet G, Mahy G (2011) Rapid restoration of a species-rich ecosystem assessed from soil and 
vegetation indicators: the case of calcareous grasslands restored from forest stands. Ecological Indicators 11:724-733

Poschlod P, WallisDeVries MF (2002) The historical and socioeconomic perspective of calcareous grasslands: lessons from the distant and recent past. Biological Conservation 104:361-376

Pywell RF, Bullock JM, Roy DB, Warman L, Walker KJ, Rothery P (2003) Plant traits as predictors of performance in ecological restoration. Journal of Applied Ecology 40:65-77

Ricklefs RE, Miller GL (2005) Ecologie. De Boeck Université Press, Bruxelles, Belgium

Rico Y, Boehmer HJ, Wagner HH (2014) Effect of rotational shepherding on demographic and genetic connectivity of calcareous grassland plants. Conservation Biology 28:467-477

Römermann C, Dutoit T, Poschlod P, Buisson E (2005) Influence of former cultivation on the unique Mediterranean steppe of France and consequences for conservation management. Biological Conservation 121:21-33

Ruiz-Jaen MC, Aide TM (2005) Restoration success: how is it being measured? Restoration Ecology 13:569-577

Schemske DW, Husband BC, Ruckelshaus MH, Goodwillie C, Parker IM, Bishop JG (1994) Evaluating approaches to the conservation of rare and endangered plants. Ecology 75:584-606

Selbo SM, Snow AA (2005) Flowering phenology and genetic similarity among local and recently introduced populations of Andropogon gerardii in Ohio. Restoration Ecology 13:441-447

Silvertown J, Charlesworth D (2001) Introduction to plant population biology. Blackwell Science Ltd, Berlin, Germany

Smulders MJM, Van Der Schoot J, Geerts RHEM, Antonisse-De Jong AG, Korevaar H, Van Der Werf A, Vosman B (2000) Genetic diversity and the reintroduction of meadow species. Plant Biology 2:447-454

Society for Ecological Restoration International Science \& Policy Working Group (2004) The SER international primer on ecological restoration. http://www.ser.org/ (accessed 29 Jan 2016)
Stromberg MR, Kephart P, Yadon V (2001) Composition, invasibility, and diversity in coastal California grasslands. Madrono 48:236-252

Usher MB (1988) Biological invasions of nature reserves: a search for generalisations. Biological Conservation 44:119-135

Vanden Broeck A, Ceulemans T, Kathagen G, Hoffmann M, Honnay O, Mergeay J (2015) Dispersal constraints for the conservation of the grassland herb Thymus pulegioides L. in a highly fragmented agricultural landscape. Conservation Genetics 16:765-776

Veldman J, Overbeck G, Negreiros D (2015a) Where tree planting and forest expansion are bad for biodiversity and ecosystem services. Bioscience 65:1011-1018

Veldman J, Overbeck G, Negreiros D, Mahy G, Le Stradic S, Fernandes G, Durigan G, Buisson E, Putz F, Bond W (2015b) Tyranny of trees in grassy biomes. Science 347:484-485

Violle C, Navas M-L, Vile D, Kazakou E, Fortunel C, Hummel I, Garnier E (2007) Let the concept of trait be functional. Oikos 116:882-892

Wagner V, Durka W, Hensen I (2011) Increased genetic differentiation but no reduced genetic diversity in peripheral vs. central populations of a steppe grass. American Journal of Botany 98:1173-1179

Wortley L, Hero JM, Howes M (2013) Evaluating ecological restoration success: a review of the literature. Restoration Ecology 21:537-543

Young A, Boyle T, Brown T (1996) The population genetic consequences of habitat fragmentation for plants. Trees 11:413-418

Young TP, Petersen DA, Clary JJ (2005) The ecology of restoration: historical links, emerging issues and unexplored realms. Ecology Letters 8:662-673

\section{Supporting Information}

The following information may be found in the online version of this article:

Table S1. List of selected papers (141 papers) and classes of population traits that were used to evaluate restoration success ("1", used in paper; " 0 ", not used in paper).

Received: 8 February, 2017; First decision: 5 May, 2017; Revised: 27 November, 2017; Accepted: 27 November, 2017; First published online: 1 January, 2018 